\title{
Accumulation of $\mathrm{M}_{1} \mathrm{dG}$ DNA adducts after chronic exposure to PCBs, but not from acute exposure to polychlorinated aromatic hydrocarbons
}

\author{
Yo-Chan Jeong ${ }^{1,5}$, Nigel J. Walker ${ }^{2}$, Deborah E. Burgin ${ }^{3}$, Grace Kissling ${ }^{2}$, Mayetri Gupta ${ }^{4}$, \\ Lawrence Kupper ${ }^{4}$, Linda S. Birnbaum ${ }^{3}$, and James A. Swenberg ${ }^{1}$ \\ 1 Department of Environmental Sciences and Engineering, University of North Carolina at Chapel Hill, NC \\ 27599 USA \\ 2 National Institute of Environmental Health Sciences, National Institutes of Health, 111 TW Alexander Drive, \\ P.O. Box 12233, MD EC-34, Research Triangle Park, NC 27709 USA
}

3 USEPA, ORD NHEERL ETD, MD-B143-01,109 TW Alexander Drive, Research Triangle Park, NC 27709 USA

4 Department of Biostatistics, University of North Carolina at Chapel Hill, NC 27599 USA

\begin{abstract}
Oxidative DNA damage is one of the key events thought to be involved in mutation and cancer. The present study examined the accumulation of $\mathrm{M}_{1} \mathrm{dG}$, 3-(2'-deoxy- $\beta$-D-erythro-pentofuranosyl)pyrimido[1,2- $a$ ]-purin-10(3H)-one, DNA adducts after single dose or one-year exposure to polyhalogenated aromatic hydrocarbons (PHAH) in order to evaluate the potential role of oxidative DNA damage in PHAH toxicity and carcinogenicity. The effect of PHAH exposure on the number of $\mathrm{M}_{1} \mathrm{dG}$ adducts was explored initially in female mice exposed to a single dose of either 2,3,7,8tetrachlorodibenzo- $p$-dioxin (TCDD) or a PHAH mixture. This study demonstrated that a single exposure to PHAH had no significant effect on the number of $\mathrm{M}_{1} \mathrm{dG}$ adducts compared to the corn oil control group. The role of $\mathrm{M}_{1} \mathrm{dG}$ adducts in polychlorinated biphenyl (PCB) induced toxicity and carcinogenicity was further investigated in rats exposed for a year to PCB 153, PCB 126, or a mixture of the two. PCB 153, at doses up to $3000 \mu \mathrm{g} / \mathrm{kg} / \mathrm{d}$, had no significant effect on the number of $\mathrm{M}_{1} \mathrm{dG}$ adducts in liver and brain tissues from the exposed rats compared to controls. However, $1000 \mathrm{ng} / \mathrm{kg} /$ $\mathrm{d}$ of $\mathrm{PCB} 126$ resulted in $\mathrm{M}_{1} \mathrm{dG}$ adduct accumulation in the liver. More importantly, co-administration of equal proportions of PCB 153 and PCB 126 resulted in dose-dependent increases in $\mathrm{M}_{1} \mathrm{dG}$ adduct accumulation in the liver from 300-1000 ng/kg/d of PCB 126 with 300-1000 $\mu \mathrm{g} / \mathrm{kg} / \mathrm{d}$ of PCB 153. Interestingly, the co-administration of different amounts of PCB 153 with fixed amounts of PCB 126 demonstrated more $\mathrm{M}_{1} \mathrm{dG}$ adduct accumulation with higher doses of PCB 153. These results are consistent with the results from cancer bioassays that demonstrated a synergistic effect between PCB 126 and PCB 153 on toxicity and tumor development. In summary, the results from the present study support the hypothesis that oxidative DNA damage plays a key role in toxicity and carcinogenicity following long-term PCB exposure.
\end{abstract}

Corresponding Author: James A. Swenberg, D.V.M. Ph.D., University of North Carolina at Chapel Hill, Rm\# 253c Rosenau Hall, CB\# 7431, Dept. of Environmental Sciences and Engineering, NC 27599-7431. Tel) 919-966-6139, Fax) 919-966-6123, Email) jswenber@email.unc.edu.

${ }^{5}$ Current Address: Toxicology \& Environmental Research and Consulting, Dow Chemical, Midland, MI 48674 USA

Publisher's Disclaimer: This is a PDF file of an unedited manuscript that has been accepted for publication. As a service to our customers we are providing this early version of the manuscript. The manuscript will undergo copyediting, typesetting, and review of the resulting proof before it is published in its final citable form. Please note that during the production process errors may be discovered which could affect the content, and all legal disclaimers that apply to the journal pertain. 


\section{Introduction}

Polyhalogenated aromatic hydrocarbons (PHAH) include polychlorinated biphenyls (PCB), polychlorinated dibenzo-p-dioxins (PCDD), and polychlorinated dibenzofurans (PCDF) (Fig. 1). These are industrial compounds or combustion byproducts that widely contaminate the environment. Therefore, humans, wildlife, and laboratory animals are exposed daily to a complex mixture of these chemicals via trace amounts present in food and the environment $[1,2]$. Due to their hydrophobic nature and resistance to metabolism, 2,3,7,8tetrachlorodibenzo-p-dioxin (TCDD) and related PHAH congeners accumulate in tissues of exposed populations [1-5]. Therefore, repeated exposures to small amounts of PHAH may evoke adverse health effects due to chronic accumulation in target tissues [6].

TCDD has been shown to act as a multi-site rodent carcinogen with potent tumor promoter activity [7]. Furthermore, increased cancer rates in humans have also been associated with exposures to dioxin-like chemicals [8-11]. Although dioxin-like compounds do not covalently bind to DNA, nor induce direct genotoxic effects, it has been suggested that DLC may be indirectly genotoxic by increasing the formation of reactive oxygen species (ROS) (Fig. 2). This increased ROS formation may result from CYP1A1 induction by PHAH [12] or from the formation of catechol estrogens [13-15].

Seven of the 75 PCDD congeners, 10 of the 135 PCDF congeners, and 13 of the 209 PCB congeners induce dioxin-like toxicity $[3,16]$. Due to the similarity in toxicity and mechanisms, the concept of toxic equivalency factors (TEF) has been used for risk assessment and regulatory control for DLC $[17,18]$. The TEF is the relative potency of biological effects assigned to each congener relative to that of TCDD on the basis of available in vivo and in vitro data $[17,18]$. This allows for the estimation of the potential dioxin-like activity of DLC mixtures in the environment. Recently, as an effort to evaluate the TEF methodology for chronic toxicity and carcinogenicity of DLC and structurally related PCB, the National Toxicology Program (NTP) conducted a series of 2-year bioassays in female Harlan Sprague-Dawley rats [19-22]. The most potent dioxin-like PCB congener, 3,3',4,4',5-pentachlorobiphenyl (PCB 126), caused dose-dependent increases in hepatic, lung, and oral mucosal neoplasms as well as in the activity of CYP 1A1 and 2B1. Interestingly, PCB 153, while it does not have dioxin-like activity, significantly enhanced carcinogenicity associated with PCB 126.

As an effort to elucidate molecular pathways involved in carcinogenesis from PHAH exposure and to develop biomarkers, this study investigated the correlation between PCB exposure and the numbers of oxidative DNA lesions. Such oxidative DNA lesions are suspected to be increased with non-DNA reactive chemicals, resulting in the induction of mutations followed by tumor formation. While base oxidation and abasic sites are the most frequent insults to DNA, substantial evidence supports that secondary DNA damage produced from byproducts of primary DNA damage or lipid membrane damage may play an important role in mutation $[23,24]$. Recently, we have developed ultra sensitive and highly specific mass spectrometric methods for the quantitation of $\mathrm{M}_{1} \mathrm{dG}$ adducts. In the follow up studies, it was established that $\mathrm{M}_{1} \mathrm{dG}$ adducts are important indirect DNA lesions primarily resulting from ROS attack on deoxyribose as well as on lipid membrane [25,26] (Fig. 2). Furthermore, $\mathrm{M}_{1} \mathrm{dG}$ adducts appear to be less prone to artifactual formation while most primary oxidative DNA lesions are significantly increased from artifactual oxidation of normal DNA nucleotides [27]. These facts support that $\mathrm{M}_{1} \mathrm{dG}$ adducts are an excellent biomarker for monitoring oxidative DNA damage from in vitro and in vivo samples. The present study investigated the numbers of $\mathrm{M}_{1} \mathrm{dG}$ adducts in tissues of rats or mice after exposures to PHAH in order to improve our understanding of the role of oxidative DNA damage in the toxicity and carcinogenicity of PHAH. 


\section{Materials and Methods}

\section{Materials and Instrumentation}

Unless stated otherwise, all chemicals and enzymes were purchased from Sigma-Aldrich Chemical Company (St Louis, MO). Proteinase K, lysis buffer, and 70\% phenol solutions were purchased from Applied Biosystems (Foster City, CA). Absolute ethanol was purchased from Aaper ethanol (Shelbyville, KY). Other solvents were HPLC grade and were purchased from Fisher Scientific (Raleigh, NC). Quantification of $\mathrm{M}_{1} \mathrm{dG}$ conjugates with tbutylhydroxylamine (tBHA) and its internal standard were performed using a Finnigan Quantum (Thermo, Woburn, MA) triple-quadrupole mass spectrometer connected to the Finnigan surveyor Micro-LC (Thermo, Woburn, MA).

\section{Exposures and tissues isolated from PHAH-exposed animals}

Female C57BL/6J mice (10 weeks old; average weight $25.6 \pm 0.4 \mathrm{~g}$ ) received a single treatment with either corn oil (i.e., vehicle) or one of the three PHAH mixtures [28]. These chemical mixtures are listed in Table 1. The ratios for Mix B were selected based on the TEF value of chemicals used and their profile detected in foods [29]. The doses used were $0,1,10 \mathrm{ng}$ toxic equivalents (TEQ) $/ \mathrm{kg} / \mathrm{d}$ body weight (BW) for Mixes A, B, and C. For TCDD exposures, the doses were $0,1,100 \mathrm{ng} / \mathrm{kg} / \mathrm{d}$ BW. Seven days after treatment, mice were euthanized by carbon dioxide anoxia and liver tissues were snap-frozen and stored in a $-80{ }^{\circ} \mathrm{C}$ freezer.

For the chronic exposure study, rat liver and brain tissues were provided by Battelle Laboratories (Columbus, $\mathrm{OH}$ ) which conducted the studies according to an NIEHS contract (N01-ES-75411) [19,30,31]. Female Harlan Sprague-Dawley rats received one of the following exposures by gavage 5 days per week for 53 weeks: PCB 153 alone; PCB 126 alone; or a mixture of PCB 153 and PCB 126 in corn oil:acetone (99:1). The doses used were 0,10 , 100,300 , and $1000 \mu \mathrm{g} / \mathrm{kg} / \mathrm{d} \mathrm{BW}$ for PCB 153, and $0,30,100,300,1000 \mathrm{ng} / \mathrm{kg} / \mathrm{d} \mathrm{BW}$ for PCB 126. The PCB mixtures were prepared in fixed proportions of PCB $153(\mu \mathrm{g} / \mathrm{kg} / \mathrm{d} \mathrm{BW})$ and PCB $126(\mathrm{ng} / \mathrm{kg} / \mathrm{d} \mathrm{BW}): 0+0 ; 10+10 ; 100+100 ; 300+300 ;$ or $1000+1000$. In addition, the following three mixture groups were used to examine the interaction between PCB $153(\mu \mathrm{g} /$ $\mathrm{kg} / \mathrm{d} \mathrm{BW}$ ) and PCB $126(\mathrm{ng} / \mathrm{kg} / \mathrm{d} \mathrm{BW}): 100+300 ; 1000+300$; or 3000+300. Liver and brain tissue samples were collected from 9 or 10 female rats per group a day after the final exposure and stored frozen at $-80^{\circ} \mathrm{C}$.

\section{DNA isolation from tissues}

DNA was extracted by a procedure described in the previous study [27]. Briefly, frozen liver or brain tissue $(1 \mathrm{~g})$ was thawed in $7 \mathrm{ml}$ ice-cold homogenization buffer consisting of phosphate buffered saline (PBS, pH 7.4) with $10 \mathrm{mM}$ 2,2,6,6-tetramethylpiperidine 1-oxyl (TEMPO). The tissue samples were homogenized with a Tehran homogenizer (Wheaton Instruments, Millville, NJ). After centrifugation at $1,000 \times \mathrm{g}$ for $15 \mathrm{~min}$, the precipitate was washed with 7 $\mathrm{ml}$ homogenization buffer. The nuclear fraction was collected by centrifugation and was reconstituted in $6 \mathrm{ml}$ lysis buffer (Applied Biosystems). Proteinase K (400 U/ml, $60 \mu \mathrm{l})$ was added to the sample and incubated overnight at $4{ }^{\circ} \mathrm{C}$. Hydrolyzed protein was then extracted twice with $6 \mathrm{ml} 70 \%$ phenol solution (Applied Biosystems) and once with $6 \mathrm{ml}$ chloroform:isoamyl alcohol (49:1, Sevag solution). Nucleic acids were precipitated from the aqueous layer by sequential addition of $300 \mu \mathrm{l} \mathrm{M} \mathrm{NaCl}$ and $12 \mathrm{ml}$ cold ethanol. The nucleic acids were collected by centrifugation and were rinsed with $6 \mathrm{ml}$ of $70 \%$ ethanol. The nucleic acid pellet was reconstituted in $2 \mathrm{ml}$ RNA digestion buffer consisting of RNase A ( $0.8 \mathrm{KeU} /$ $\mathrm{ml})$, RNase T1 (3 mU/ml), and $1 \mathrm{mM}$ TEMPO in $10 \mathrm{mM}$ HEPES buffer (pH 7.8). After 1 hour incubation at $37^{\circ} \mathrm{C}$, DNA was precipitated by the sequential addition of $100 \mu \mathrm{l} 3 \mathrm{M} \mathrm{NaCl}$ and $4 \mathrm{ml}$ cold ethanol. The DNA was collected by centrifugation and rinsed with $70 \%$ ethanol. The DNA pellet was resuspended in $1 \mathrm{ml}$ HPLC grade water. DNA samples $(25 \mu \mathrm{l})$ were mixed 
with $975 \mu \mathrm{l} 20 \mathrm{mM}$ Tris-EDTA buffer (TE, $\mathrm{pH} 8.0$ ) to measure DNA concentration and purity by $\mathrm{UV}$. The DNA solution was stored at $-80^{\circ} \mathrm{C}$ until $\mathrm{M}_{1} \mathrm{dG}$ adduct analysis.

\section{Analysis of $M_{1} d G$ adducts in DNA}

The number of $\mathrm{M}_{1} \mathrm{dG}$ adducts in sample DNA was determined by the derivatization of DNA adducts with tBHA and LC-MS/MS analysis for the $\mathrm{M}_{1} \mathrm{dG}$-tBHA conjugate similar to the protocol described elsewhere [32]. Briefly, sample DNA (200 $\mu \mathrm{g})$ was mixed with internal standard (IS) DNA corresponding to $400 \mathrm{fmol}{ }^{15} \mathrm{~N}_{5}-\mathrm{M}_{1} \mathrm{G}-\mathrm{dR}$. The DNA mix was incubated with $2 \mathrm{mM}$ tBHA in $10 \mathrm{mM} \mathrm{KHPO}_{4}\left(\mathrm{pH}\right.$ 5.5) solution for $30 \mathrm{~min}$ at $50^{\circ} \mathrm{C}$. Free tBHA in the sample solution was removed by DNA precipitation after sequential additions of $1 / 20$ volume of $3 \mathrm{M}$ sodium acetate and 1 volume of isopropanol. The sample DNA was reconstituted in $570 \mu \mathrm{L}$ of $20 \mathrm{mM}$ HEPES buffer (pH 7.4) containing $1 \mathrm{mM} \mathrm{MgCl}_{2}$ and $100 \mathrm{U} / \mathrm{mL}$ DNase I. The DNA was hydrolyzed to nucleosides for $20 \mathrm{~min}$ at $37^{\circ} \mathrm{C}$, followed by the addition of 30 $\mu \mathrm{l}$ solution containing alkaline phosphatase and phosphodiesterase I to final concentrations of 5 and $0.06 \mathrm{U} / \mathrm{mL}$, respectively. The DNA and enzyme mixture was further incubated at $37^{\circ} \mathrm{C}$ for $1 \mathrm{~h}$ with mild agitation. The hydrolyzed DNA was placed on an SPE column (HLB-60, Waters, Milford, MA) that had been preactivated with methanol and equilibrated with water. The SPE column was washed with $1 \mathrm{~mL}$ water and with $3 \mathrm{~mL} 40 \%$ methanol. $\mathrm{M}_{1} \mathrm{dG}$-tBHA and the internal standard were eluted with $1 \mathrm{~mL}$ of $90 \%$ methanol in water. The solvent was removed by vacuum evaporation. The samples were reconstituted in $50 \mu \mathrm{L}$ of $10 \%$ methanol in water and stored at $-80^{\circ} \mathrm{C}$ until analysis.

$\mathrm{M}_{1} \mathrm{dG}$-tBHA and IS were separated on an Aquasile column $(5 \mu \mathrm{m}, 1 \mathrm{~mm} \times 150 \mathrm{~mm}$, Thermo) at a flow rate of $100 \mu \mathrm{L} / \mathrm{min}$. The analysis was performed by positive ion electrospray using SRM. Nitrogen gas was used for the sheath and auxiliary gas. Fragmentation was accomplished at $38 \mathrm{~V}$ using argon gas at $1.5 \mathrm{mTorr}$. Two ion transitions, $\mathrm{m} / \mathrm{z} 635 \rightarrow \mathrm{m} / \mathrm{z} 188$ and $\mathrm{m} / \mathrm{z} 640 \rightarrow$ $m / z 193$, were used to monitor $\mathrm{M}_{1} \mathrm{dG}$ and ${ }^{15} \mathrm{~N}_{5}-\mathrm{M}_{1} \mathrm{dG}$.

\section{Statistical Analyses}

Statistical analyses were performed using SAS Ver. 8.02 (Cary, NC) and nonlinear equations were solved numerically using Matlab Ver. 7.3 (The Mathworks, Natick, MA). The effect of chemical exposures on the accumulation of $\mathrm{M}_{1} \mathrm{dG}$ DNA adducts was assessed with one-way ANOVA after the homogeneity of variances was verified with O'Brien's test and normality of residuals with the Kolmogorov-Smirnov test [33]. Plots for $\mathrm{M}_{1} \mathrm{dG}$ DNA adducts in rat liver were fitted using linear regression to test PCB-dose dependency in the accumulation of $\mathrm{M}_{1} \mathrm{dG}$ adducts. Differences between control and PCB-treated rats in the number of $\mathrm{M}_{1} \mathrm{dG}$ adducts were assessed by planned pairwise comparisons after the means were adjusted by Dunnett's method for multiple comparisons [34]. In cases where the sample size was limited, the nonparametric Jonckheere-Terpstra exact test was used to assess the trend in the number of $\mathrm{M}_{1} \mathrm{dG}$ adducts over different doses [35]. Two-sided and one-sided $p$-values were considered significant if they were less than 0.05 .

\section{Results and Discussion}

The major goal of this research was to test the hypothesis that PHAH exposures increase ROS generation, which in turn results in higher numbers of $\mathrm{M}_{1} \mathrm{dG}$ adducts in genomic DNA. As an initial approach to test the hypothesis, the effect of TCDD on the number of $\mathrm{M}_{1} \mathrm{dG}$ adducts was examined using mice treated with single doses of different amounts of TCDD. In a parallel experiment, different combinations of PHAH mixtures were given to mice to evaluate the TEF methodology in their toxicities, including oxidative DNA damage. Mix A consisted of DLC including TCDD. Mix B consisted of non-dioxin like PCB that are major PCB congeners found in the environment. To emulate environmental exposures which include a mixture of PHAH, 
mix $\mathrm{C}$ consisted of a combination of mix A and mix B. The toxicity and the change in the number of $\mathrm{M}_{1} \mathrm{dG}$ adducts were examined a week after PHAH treatment.

A previous study [28] had shown that TCDD treatment resulted in a dose-dependent increase in the concentration of malondialdehyde (i.e., a major precursor to $\mathrm{M}_{1} \mathrm{dG}$ adduct formation) in the livers of these mice. Cytochrome $\mathrm{C}$ reduction (i.e., an indicator of superoxide anion radical production) showed statistically significant increases in mice that received 10 or 100 $\mu \mathrm{g} / \mathrm{kg} / \mathrm{d}$ of TCDD [28]. However, as described in Fig. 3, there was no trend in the numbers of $\mathrm{M}_{1} \mathrm{dG}$ DNA adducts in response to the different doses of TCDD or one of the PHAH mixtures (non-parametric Jonckheere-Terpstra exact test, $p>0.18$ ). This result is consistent with the findings from other investigators who reported no significant changes in the numbers of 8-OH$\mathrm{dG}$ adducts after a single exposure to DLC [36,37]. In contrast, subchronic or chronic exposures to the chemicals resulted in an accumulation of $8-\mathrm{OH}-\mathrm{dG}$ adducts in animals $[36,37]$.

It has been hypothesized by a number of investigators [12,37] that DNA repair in healthy control animals is sufficient to repair DNA adducts formed by an acute exposure to PHAH. Unlike acute exposures, however, long-term exposures to PHAH may change the capacity of DNA repair by modifying the expression of proteins involved in DNA repair, analogous to how PHAH changes the expression of metabolic enzymes [38-40]. Additionally, it has been proposed that DNA repair proteins can be impaired by mutations caused by the slow accumulation of DNA adducts over a long period of time [37]. This argument is supported by the findings from previous studies that reported sustained DNA adduct (i.e., 8-OH-dG) accumulation, toxicity, and carcinogenesis $[12,36,37,41]$.

To determine the role of oxidative DNA damage in the toxicity and carcinogenicity of PCBs, the accumulation of $\mathrm{M}_{1} \mathrm{dG}$ adducts in livers and brain was examined in rats that had been exposed for a year to PCB 153, PCB 126, or a mixture of PCB 153 and PCB 126. As shown in Fig. 4, PCB exposure produced statistically significant changes in the accumulation of hepatic $\mathrm{M}_{1} \mathrm{dG}$ adducts in the rats exposed to PCB $126(\mathrm{~F}(4,35)=13.31, p<.0001)$ or to the mixture of PCB 126 and PCB 153 in a 1:1000 ratio $(\mathrm{F}(4,35)=19.44, p<.0001)$. There was no significant effect of PCB 153 exposure on $\mathrm{M}_{1} \mathrm{dG}$ DNA adduct accumulation in rat liver ( $\mathrm{F}$ $(4,33)=1.32, p=.2820)$. Linear regression confirmed dose-dependent increases in the numbers of $\mathrm{M}_{1} \mathrm{dG}$ adducts in the rats exposed to PCB $126\left(R^{2}=.5851, p<.0001\right)$ or to the mixture of PCB 126 and PCB $153\left(R^{2}=.6880, p<.0001\right)$. Interestingly, analyses of the linear regression model revealed that the mixture of PCB 126 and PCB 153 had a stronger effect on the accumulation of hepatic $\mathrm{M}_{1} \mathrm{dG}$ adducts than PCB 126 alone $(p=.0013)$. The response to the mixture of PCB 126 and PCB 153 in the accumulation of hepatic $\mathrm{M}_{1} \mathrm{dG}$ adducts was even stronger than the sum of the individual response to PCB 126 and PCB $153(p=.0027)$. Compared to the control, PCB 126 resulted in significantly increased accumulation of $\mathrm{M}_{1} \mathrm{dG}$ adducts in rat liver at $1000 \mathrm{ng} / \mathrm{kg}$. However, by co-administrating a 1000-fold excess of PCB 153 , PCB 126 produced significantly higher numbers of $\mathrm{M}_{1} \mathrm{dG}$ adduct in rat liver at $300 \mathrm{ng} /$ $\mathrm{kg} /$ as well as at $1000 \mathrm{ng} / \mathrm{kg} / \mathrm{d}$ when the numbers were compared to that of control rats. $(p=$. 0274 , and $p<.0001$, respectively). These results provide strong evidence in support of the hypothesis that long-term exposure to PCB causes the accumulation of oxidative DNA lesions that may play a role in toxicity, mutation and cancer development. Furthermore, the results from this study support the hypothesis that PCB 153 which is a non-dioxin like PCB potentiates the PCB 126 mediated DNA damage.

This hypothesis was further tested in the experiments with rats that were dosed with fixed amounts of PCB $126(300 \mathrm{ng} / \mathrm{kg} / \mathrm{d})$ in combination of different amounts of PCB 153 . The effect of PCB treatments on hepatic $M_{1} d G$ adducts is shown in Fig. 5. The number of $M_{1} d G$ adducts in livers for the mixture of PCB 126/PCB 153 at 300/3000 was significantly higher compared to both $300 / 0(p<.0001)$ and $0 / 3000(p<.0001)$ (Fig. 5A. A positive linear association $\left(R^{2}\right.$ 
$=.603, p<.0001)$ was confirmed between the number of $\mathrm{M}_{1} \mathrm{dG}$ adducts in liver and the amount of PCB 153 when the rats were co-administered $300 \mathrm{ng} / \mathrm{kg} / \mathrm{d}$ PCB 126 (Fig 5B). Overall, these results support the hypothesis that non-dioxin like PHAH can significantly increase DNA damage resulting from simultaneous exposures to DLC.

The effect of PCB exposure on the accumulation of $\mathrm{M}_{1} \mathrm{dG}$ adducts in the brain was examined and the results are described in Fig. 6. There was no trend in the number of $\mathrm{M}_{1} \mathrm{dG}$ adducts in response to the different doses of either PCB 153 alone or the mixture of PCB 153 and PCB 126 (non-parametric Jonckheere-Terpstra exact test, $p>$.28). The effect of PCB 126 exposure on $\mathrm{M}_{1} \mathrm{dG}$ accumulation was not examined because tissue samples were not available.

Finally, the results from this study were compared to those from the NTP cancer bioassays [30]. The NTP reported that increasing the proportion of PCB 153 in the mixtures of PCB 126 resulted in increases in cell proliferation in rat liver. Furthermore, there was a positive effect of PCB 153 in the PCB 153/ PCB 126 mixture on liver toxicity, including hepatocyte hypertrophy, cholangiofibrosis, eosinophilic foci, clear cell foci, basophilic foci, diffuse and focal fatty change, bile duct hyperplasia, and hematopoietic cell proliferation. Carcinogenesis was also enhanced after a two-year exposure. A positive effect of increasing the amount of PCB 153 in the mixture was evident in increased incidences of hepatocellular adenoma and cholangiocarcinoma. As described in Fig. 7, the dose response for $\mathrm{M}_{1} \mathrm{dG}$ adduct accumulation after PCB exposure is very similar to that of developing neoplastic lesions. The number of $\mathrm{M}_{1} \mathrm{dG}$ adducts in liver showed positive correlations with the incidence of hepatocellular adenoma and cholangiocarcinoma. It is noteworthy that the change in the number of hepatic $\mathrm{M}_{1} \mathrm{dG}$ adducts was detected after a one-year exposure to PCBs while the increase in cancer incidence was observed after a two-year exposure to PCBs. This result supports the hypothesis that oxidative DNA damage plays an important role in cancer development associated with chronic exposure to PHAHs. Compared to other biomarkers such as cell proliferation and cytochrome P450 expression that have been used in the TEF evaluation for PHAHs, the numbers of hepatic $\mathrm{M}_{1} \mathrm{dG}$ adducts showed strong positive correlations to the incidence of neoplastic lesions in the rats treated with the mixture of PCBs.

PCB153, which does not have a TEF value since it has no dioxin like effects, enhances the accumulation of oxidative DNA lesions in genomic DNA, thus increasing chances for toxicity, mutation and cancer development. Similar to these results, the synergistic effect of PCB 153 with DLC other than PCB 126 on the toxicity of DLC has been previously reported. Van Birgelen [42] demonstrated a synergistic effect of co-administration of PCB 153 and TCDD on hepatic porphyrin accumulation in female Sprague-Dawley rats fed diets containing these chemicals for 13 weeks. To explore this synergistic effect of PCB 153 on the toxicity of DLC, a number of researchers investigated the role of PCB 153 and found that it increased the hepatic concentrations of DLC $[43,44]$. PCB 153 was shown to enhance the retention of DLC in the cell by inducing both AhR and CYP1A2, the two major binding proteins for DLC [45,46]. However, analysis of hepatic PCB 126 concentrations by the NTP as a part of the cancer bioassay, showed that the proportion of PCB 153 in the mixture relative to PCB 126 had no significant effect on the amounts of PCB 126 in liver and lung tissues [30]. Consistent with this result, hepatic CYP1A1 and CYP1A2 enzyme activities were not affected by the proportion of PCB 153 in mixtures with constant amounts of PCB 126. Therefore, the molecular mechanism involved in this synergistic effect between PCB 126 and PCB 153 on $\mathrm{M}_{1} \mathrm{dG}$ adduct accumulation in the liver requires additional research.

In summary, the present study supports the hypothesis that oxidative DNA damage plays an important role in the toxicity and carcinogenicity associated with chronic exposure to PHAHs. The accumulation of $\mathrm{M}_{1} \mathrm{dG}$ adducts in the tissues were dose- and time-dependent on PHAH exposure, which is similar to the incidence of pre-neoplastic lesions and subsequent cancer 
development. Enhanced DLC toxicities (i.e., the accumulation of $\mathrm{M}_{1} \mathrm{dG}$ adducts and preneoplastic lesions in liver) by non-dioxin like PHAH suggest that the combination of different types of PHAH can result in greater toxicity than predicted by TEFs. Overall, the findings from the present study provide additional information that may be important in the scientific assessment of risk for complex PHAH mixtures present in the environment.

\section{Acknowledgements}

We thank Drs. Michael Wyde and Ivan Rusyn for a critical reading of the manuscript; Dr. Valeriy V. Afonin for his technical assistance in DNA isolation; and Daniela Sotres-Alvarez for her assistance in statistical analyses. This research was supported in part by the NIEHS Superfund Basic Research Program P42-ES05948, NIH grants R42ES11746 and P30-ES10126, and the Intramural Research Program of the NIH and NIEHS. Partial funding was provided by the NHEERL-DESE Training in Environmental Sciences Research, EPA CT902908 and T32-ES07126. The information in this document has been subjected to review and approved for publication by the National Health and Environmental Effects Research Laboratory, U.S. Environmental Protection Agency, and by NIEHS, NIH. Approval does not signify that the contents reflect the views of the Agency, nor does mention of trade names or commercial products constitute endorsement or recommendation for use.

\section{References}

1. DeVito MJ, Birnbaum LS, Farland WH, Gasiewicz TA. Comparisons of estimated human body burdens of dioxinlike chemicals and TCDD body burdens in experimentally exposed animals. Environ Health Perspect 1995;103:820-831. [PubMed: 7498094]

2. Vanden Heuvel JP, Clark GC, Tritscher A, Lucier GW. Accumulation of polychlorinated dibenzo-pdioxins and dibenzofurans in liver of control laboratory rats. Fundam Appl Toxicol 1994;23:465-469. [PubMed: 7835546]

3. Safe S. Polychlorinated biphenyls (PCBs), dibenzo-p-dioxins (PCDDs), dibenzofurans (PCDFs), and related compounds: environmental and mechanistic considerations which support the development of toxic equivalency factors (TEFs). Crit Rev Toxicol 1990;21:51-88. [PubMed: 2124811]

4. Schecter A, Startin J, Wright C, Kelly M, Papke O, Lis A, Ball M, Olson JR. Congener-specific levels of dioxins and dibenzofurans in U.S. food and estimated daily dioxin toxic equivalent intake. Environ Health Perspect 1994;102:962-966. [PubMed: 9738211]

5. Schecter A, Stanley J, Boggess K, Masuda Y, Mes J, Wolff M, Furst P, Furst C, Wilson-Yang K, Chisholm B. Polychlorinated biphenyl levels in the tissues of exposed and nonexposed humans. Environ Health Perspect 1994;102:149-158. [PubMed: 8187704]

6. Slezak BP, Hatch GE, DeVito MJ, Diliberto JJ, Slade R, Crissman K, Hassoun E, Birnbaum LS. Oxidative stress in female B6C3F1 mice following acute and subchronic exposure to 2,3,7,8tetrachlorodibenzo-p-dioxin (TCDD). Toxicol Sci 2000;54:390-398. [PubMed: 10774821]

7. Dragan YP, Schrenk D. Animal studies addressing the carcinogenicity of TCDD (or related compounds) with an emphasis on tumour promotion. Food Addit Contam 2000;17:289-302. [PubMed: 10912243]

8. Bertazzi PA, Riboldi L, Pesatori A, Radice L, Zocchetti C. Cancer mortality of capacitor manufacturing workers. Am J Ind Med 1987;11:165-176. [PubMed: 3103429]

9. Brown DP. Mortality of workers exposed to polychlorinated biphenyls--an update. Arch Environ Health 1987;42:333-339. [PubMed: 3125795]

10. Kimbrough RD. Laboratory and human studies on polychlorinated-biphenyls (PCBs) and relatedcompounds. Environ Health Perspect 1985;59:99-106. [PubMed: 3921372]

11. Sinks T, Steele G, Smith AB, Watkins K, Shults RA. Mortality among workers exposed to polychlorinated biphenyls. Am J Epidemiol 1992;136:389-398. [PubMed: 1415158]

12. Park JY, Shigenaga MK, Ames BN. Induction of cytochrome P4501 A1 by 2,3,7,8-tetrachlorodibenzop-dioxin or indolo(3,2-b)carbazole is associated with oxidative DNA damage. Proc Natl Acad Sci U S A 1996;93:2322-2327. [PubMed: 8637871]

13. Graham MJ, Lucier GW, Linko P, Maronpot RR, Goldstein JA. Increases in cytochrome P-450 mediated 17 beta-estradiol 2-hydroxylase activity in rat liver microsomes after both acute administration and subchronic administration of 2,3,7,8-tetrachlorodibenzo-p-dioxin in a two-stage hepatocarcinogenesis model. Carcinogenesis 1988;9:1935-1941. [PubMed: 3141074] 
14. Yager JD, Liehr JG. Molecular mechanisms of estrogen carcinogenesis. Annu Rev Pharmacol Toxicol 1996;36:203-232. [PubMed: 8725388]

15. Spink DC, Eugster HP, Lincoln DW, Schuetz JD, Schuetz EG, Johnson JA, Kaminsky LS, Gierthy JF. 17 beta-estradiol hydroxylation catalyzed by human cytochrome P450 1A1: a comparison of the activities induced by 2,3,7,8-tetrachlorodibenzo-p-dioxin in MCF-7 cells with those from heterologous expression of the cDNA. Arch Biochem Biophys 1992;293:342-348. [PubMed: 1536570]

16. Safe SH. Polychlorinated biphenyls (PCBs): environmental impact, biochemical and toxic responses, and implications for risk assessment. Crit Rev Toxicol 1994;24:87-149. [PubMed: 8037844]

17. Van den Berg M, Birnbaum L, Bosveld ATC, Brunstrom B, Cook P, Feeley M, Giesy JP, Hanberg A, Hasegawa R, Kennedy SW, Kubiak T, Larsen JC, van Leeuwen FXR, Liem AKD, Nolt C, Peterson RE, Poellinger L, Safe S, Schrenk D, Tillitt D, Tysklind M, Younes M, Waern F, Zacharewski T. Toxic equivalency factors (TEFs) for PCBs, PCDDs, PCDFs for humans and wildlife. Environ Health Perspect 1998;106:775-792. [PubMed: 9831538]

18. Van den BM, Birnbaum LS, Denison M, De VM, Farland W, Feeley M, Fiedler H, Hakansson H, Hanberg A, Haws L, Rose M, Safe S, Schrenk D, Tohyama C, Tritscher A, Tuomisto J, Tysklind M, Walker N, Peterson RE. The 2005 World Health Organization reevaluation of human and Mammalian toxic equivalency factors for dioxins and dioxin-like compounds. Toxicol Sci 2006;93:223-241. [PubMed: 16829543]

19. National Toxicology Program. NTP Toxicology and carcinogenesis studies of 3,3',4,4',5pentachlorobiphenyl (PCB 126) (CAS No. 57465-28-8) in female Harlan Sprague-Dawley rats (Gavage Studies). Natl Toxicol Program Tech Rep Ser 2006:4-246.

20. National Toxicology Program. NTP technical report on the toxicology and carcinogenesis studies of 2,3,7,8-tetrachlorodibenzo-p-dioxin (TCDD) (CAS No. 1746-01-6) in female Harlan SpragueDawley rats (Gavage Studies). Natl Toxicol Program Tech Rep Ser 2006:4-232.

21. National Toxicology Program. NTP Toxicology and Carcinogenesis Studies of 2,3,4,7,8Pentachlorodibenzofuran (PeCDF) (CAS No. 57117-31-4) in Female Harlan Sprague-Dawley Rats (Gavage Studies). Natl Toxicol Program Tech Rep Ser 2006:1-198.

22. National Toxicology Program. NTP technical report on the toxicology and carcinogenesis studies of a xixture of 2,3,7,8-tetrachlorodibenzo-p-Dioxin (TCDD) (CAS No. 1746-01-6), 2,3,4,7,8pentachlorodibenzofuran (PeCDF) (CAS No. 57117-31-4), and 3,3',4,4',5-pentachlorobiphenyl (PCB 126) (CAS No. 57465-28-8) in female Harlan Sprague-Dawley rats (Gavage Studies). Natl Toxicol Program Tech Rep Ser 2006:4-180.

23. Ham AJ, Ranasinghe A, Koc H, Swenberg JA. 4-Hydroxy-2-nonenal and ethyl linoleate form $\mathrm{N}^{2}$,3ethenoguanine under peroxidizing conditions. Chem Res Toxicol 2000;13:1243-1250. [PubMed: 11123965]

24. Morinello EJ, Ham AJ, Ranasinghe A, Nakamura J, Upton PB, Swenberg JA. Molecular dosimetry and repair of $\mathrm{N}^{2}, 3$-ethenoguanine in rats exposed to vinyl chloride. Cancer Res 2002;62:5189-5195. [PubMed: 12234983]

25. Dedon PC, Plastaras JP, Rouzer CA, Marnett LJ. Indirect mutagenesis by oxidative DNA damage: Formation of the pyrimidopurinone adduct of deoxyguanosine by base propenal. Proc Natl Acad Sci U S A 1998;95:11113-11116. [PubMed: 9736698]

26. Jeong YC, Swenberg JA. Formation of $\mathrm{M}_{1} \mathrm{G}-\mathrm{dR}$ from endogenous and exogenous ROS inducing chemicals. Free Radic Biol Med 2005;39:1021-1029. [PubMed: 16198229]

27. Jeong YC, Nakamura J, Upton PB, Swenberg JA. Pyrimido[1,2-a]-purin-10(3H)-one, M1G, is less prone to artifact than base oxidation. Nucleic Acids Res 2005;33:6426-6434. [PubMed: 16282591]

28. Burgin, Deborah Elizabeth. Evaluation of the dioxin TEQ approach in predicting multiple responses due to commercial and environmentally-relevant polychlorinated biphenyl mixtures. The University of North Carolina at Chapel Hill; 2004.

29. Birnbaum LS, DeVito MJ. Use of toxic equivalency factors for risk assessment for dioxins and related compounds. Toxicology 1995;105:391-401. [PubMed: 8571375]

30. National Toxicology Program. NTP Toxicology and Carcinogenesis Studies of a Binary Mixture of 3,3',4,4',5-Pentachlorobiphenyl (PCB 126) (CAS No. 57465-28-8) and 2,2',4,4',5,5'- 
Hexachlorobiphenyl (PCB 153) (CAS No. 35065-27-1) in Female Harlan Sprague-Dawley Rats (Gavage Studies). Natl Toxicol Program Tech Rep Ser 2006:1-258.

31. National Toxicology Program. NTP technical report on the toxicology and carcinogenesis studies of 2,2',4,4',5,5'-hexachlorobiphenyl (PCB 153) (CAS No. 35065-27-1) in female Harlan SpragueDawley rats (Gavage studies). Natl Toxicol Program Tech Rep Ser 2006:4-168.

32. Jeong YC, Sangaiah R, Nakamura J, Pachkowski BF, Ranasinghe A, Gold A, Ball LM, Swenberg JA. Analysis of $\mathrm{M}_{1} \mathrm{G}-\mathrm{dR}$ in DNA by aldehyde reactive probe labeling and liquid chromatography tandem mass spectrometry. Chem Res Toxicol 2005;18:51-60. [PubMed: 15651849]

33. Kleinbaum, DG.; Kupper, LL.; Muller, KE.; Nizam, A. Applied regression analysis and other multivariable methods. Pacific Grove, NY: Duxbury Press; 1998.

34. Muller, KE.; Fetterman, BA. Regression and ANOVA: An Integrated Approach Using SAS Software. Cary, NC: SAS Institute; 2003.

35. Higgins, JJ. An introduction to modern nonparametric statistics. Pacific Grove, CA: Brooks/Cole; 2004.

36. Tritscher AM, Seacat AM, Yager JD, Groopman JD, Miller BD, Bell D, Sutter TR, Lucier GW. Increased oxidative DNA damage in livers of 2,3,7,8-tetrachlorodibenzo-p-dioxin treated intact but not ovariectomized rats. Cancer Lett 1996;98:219-225. [PubMed: 8556712]

37. Wyde ME, Wong VA, Kim AH, Lucier GW, Walker NJ. Induction of hepatic 8-oxo-deoxyguanosine adducts by 2,3,7,8-tetrachlorodibenzo-p-dioxin in Sprague-Dawley rats is female-specific and estrogen-dependent. Chem Res Toxicol 2001;14:849-855. [PubMed: 11453731]

38. Chan CY, Kim PM, Winn LM. TCDD affects DNA double strand-break repair. Toxicol Sci 2004;81:133-138. [PubMed: 15201442]

39. Rattenborg T, Gjermandsen I, Bonefeld-Jorgensen EC. Inhibition of E2-induced expression of BRCA1 by persistent organochlorines. Breast Cancer Res 2002;4:R12. [PubMed: 12473173]

40. Shertzer HG, Nebert DW, Puga A, Ary M, Sonntag D, Dixon K, Robinson LJ, Cianciolo E, Dalton TP. Dioxin causes a sustained oxidative stress response in the mouse. Biochem Biophys Res Commun 1998;253:44-48. [PubMed: 9875217]

41. Kociba RJ, Keyes DG, Beyer JE, Carreon RM, Wade CE, Dittenber DA, Kalnins RP, Frauson LE, Park CN, Barnard SD, Hummel RA, Humiston CG. Results of a two-year chronic toxicity and oncogenicity study of 2,3,7,8-tetrachlorodibenzo-p-dioxin in rats. Toxicol Appl Pharmacol 1978;46:279-303. [PubMed: 734660]

42. van Birgelen AP, Fase KM, van der KJ, Poiger H, Brouwer A, Seinen W, van den BM. Synergistic effect of 2,2',4,4',5,5'-hexachlorobiphenyl and 2,3,7,8-tetrachlorodibenzo-p-dioxin on hepatic porphyrin levels in the rat. Environ Health Perspect 1996;104:550-557. [PubMed: 8743444]

43. van der Plas SA, Haag-Gronlund M, Scheu G, Warngard L, van den BM, Wester P, Koeman JH, Brouwer A. Induction of altered hepatic foci by a mixture of dioxin-like compounds with and without 2,2',4,4',5,5'-hexachlorobiphenyl in female Sprague-Dawley rats. Toxicol Appl Pharmacol 1999;156:30-39. [PubMed: 10101096]

44. De Jongh J, DeVito M, Diliberto J, Van den BM, Birnbaum L. The effects of 2,2',4,4',5,5'hexachlorobiphenyl cotreatment on the disposition of 2,3,7,8-tetrachlorodibenzo-p-dioxin in mice. Toxicol Lett 1995;80:131-137. [PubMed: 7482580]

45. deJongh J, Wondergem F, Seinen W, Vanden BM. Toxicokinetic interactions between chlorinated aromatic hydrocarbons in the liver of the C57BL/6J mouse: I. Polychlorinated biphenyls (PCBs). Arch Toxicol 1993;67:453-460. [PubMed: 8239993]

46. Bannister R, Safe S. Synergistic interactions of 2,3,7,8-TCDD and 2,2',4,4',5,5'-hexachlorobiphenyl in C57BL/6J and DBA/2J mice: role of the Ah receptor. Toxicology 1987;44:159-169. [PubMed: 3031851] 
A. Dioxins and Dioxin-like compounds<smiles>Clc1cc2c(cc1Cl)Oc1cc(Cl)c(Cl)cc1O2</smiles>

TCDD<smiles>Clc1cc2c(cc1Cl)Oc1c(cc(Cl)c(Cl)c1Cl)O2</smiles>

PeCDD<smiles>Clc1cc2oc3cc(Cl)c(Cl)c(Cl)c3c2cc1Cl</smiles>

4-PCDF<smiles>Clc1ccc(-c2cc(Cl)c(Cl)c(Cl)c2)cc1Cl</smiles>

PCB 126

B. Non Dioxin-like PCBs

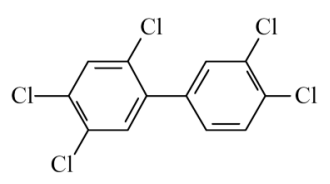

PCB 138<smiles>ClC1=CC(Cl)C(Cl)C=C1C1=CCC(Cl)C(Cl)=C1Cl</smiles>

PCB 118<smiles>ClC1=CC(Cl)C(Cl)C=C1C1=CC(Cl)C(Cl)C=C1Cl</smiles>

PCB 153<smiles>ClC1=CC(Cl)C(Cl)C=C1C1=CC(Cl)C(Cl)C(Cl)=C1Cl</smiles>

PCB 180

Fig. 1. Polyhalogenated Aromatic Hydrocarbons (PHAH) 


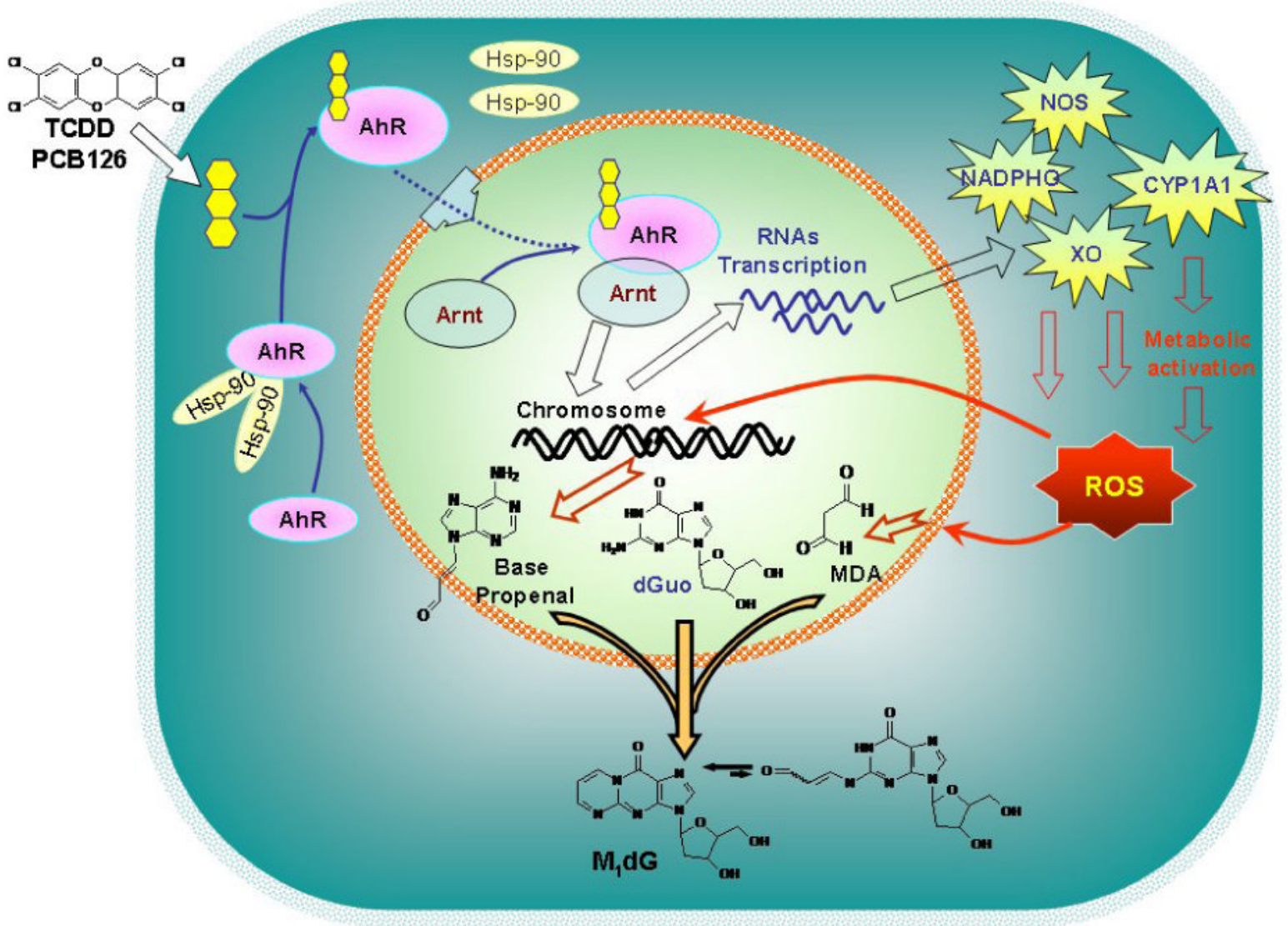

Fig. 2. Pathways leading to production of ROS from DLC exposure, and to formation of $M_{1} d G$ DNA adducts from ROS attack on lipid membranes and on DNA backbone

AhR: aryl hydrocarbon receptor, HSP-90: heat-shock protein -90, Arnt: aryl hydrocarbon receptor nuclear translocator, NADPHO: nicotinamide adenosine dinucleotide phosphate oxidase, NOS: nitric oxide synthase, XO: xanthine oxidase, MDA: malondialdehyde 


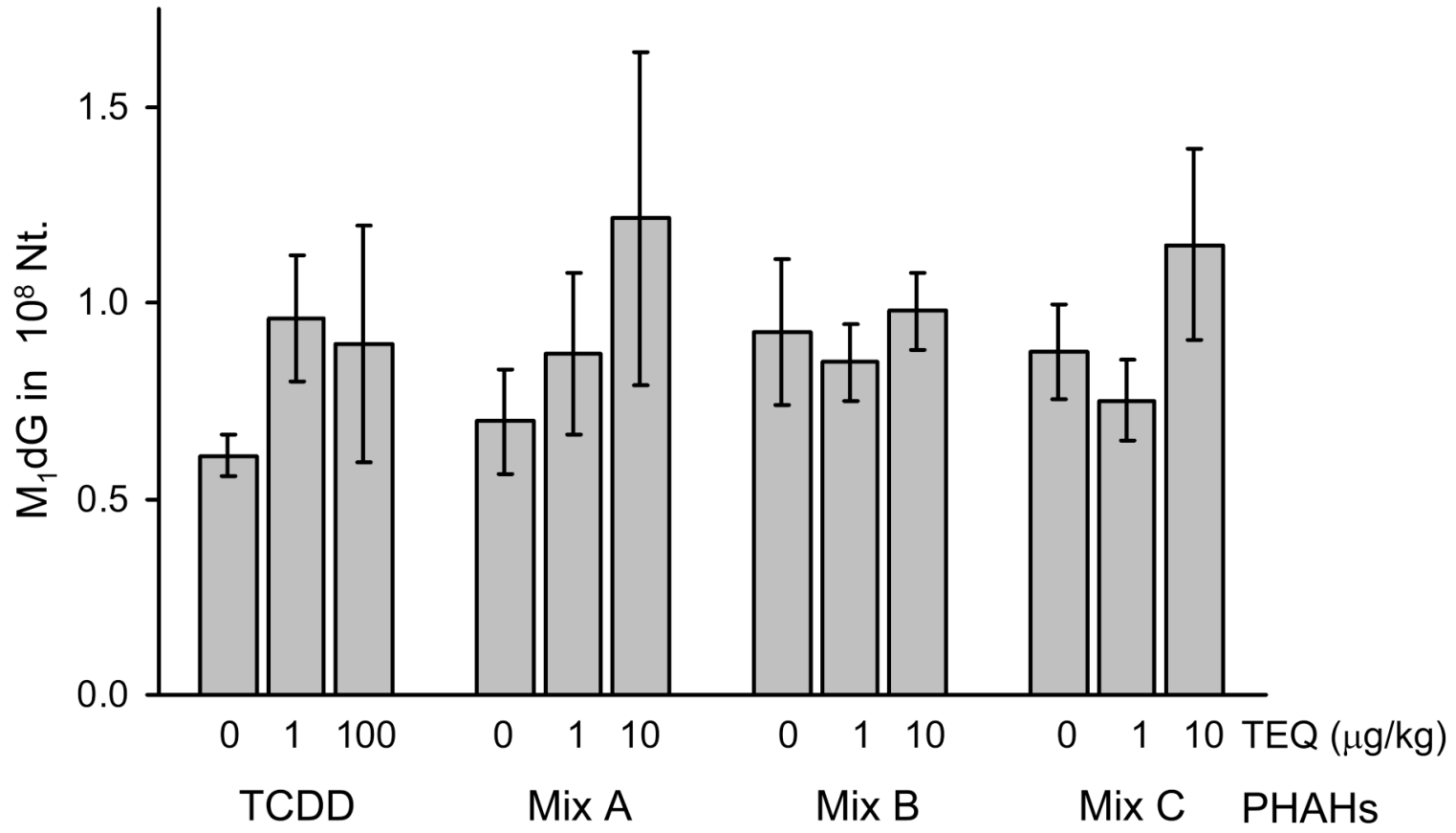

Fig. 3. Effect of single dose of TCDD or PHAH mixture on the background level of hepatic $M_{1} \mathrm{dG}$ adducts

Female C57BL/6J mice received a single treatment with corn oil containing either TCDD or one of the PHAH mixtures; Mix A(TCDD, PeCDD, 4-PCDF, PCB 126); Mix B(PCB 118, PCB 138, PCB 153, PCB 180); or Mix C(Mix A + Mix B). The ratios for the mixtures were selected based on the profile observed in foods. Liver tissues were collected a week after the treatment and subjected to DNA isolation. Each bar represents the mean + S.E. from 4-5 samples for each group. 


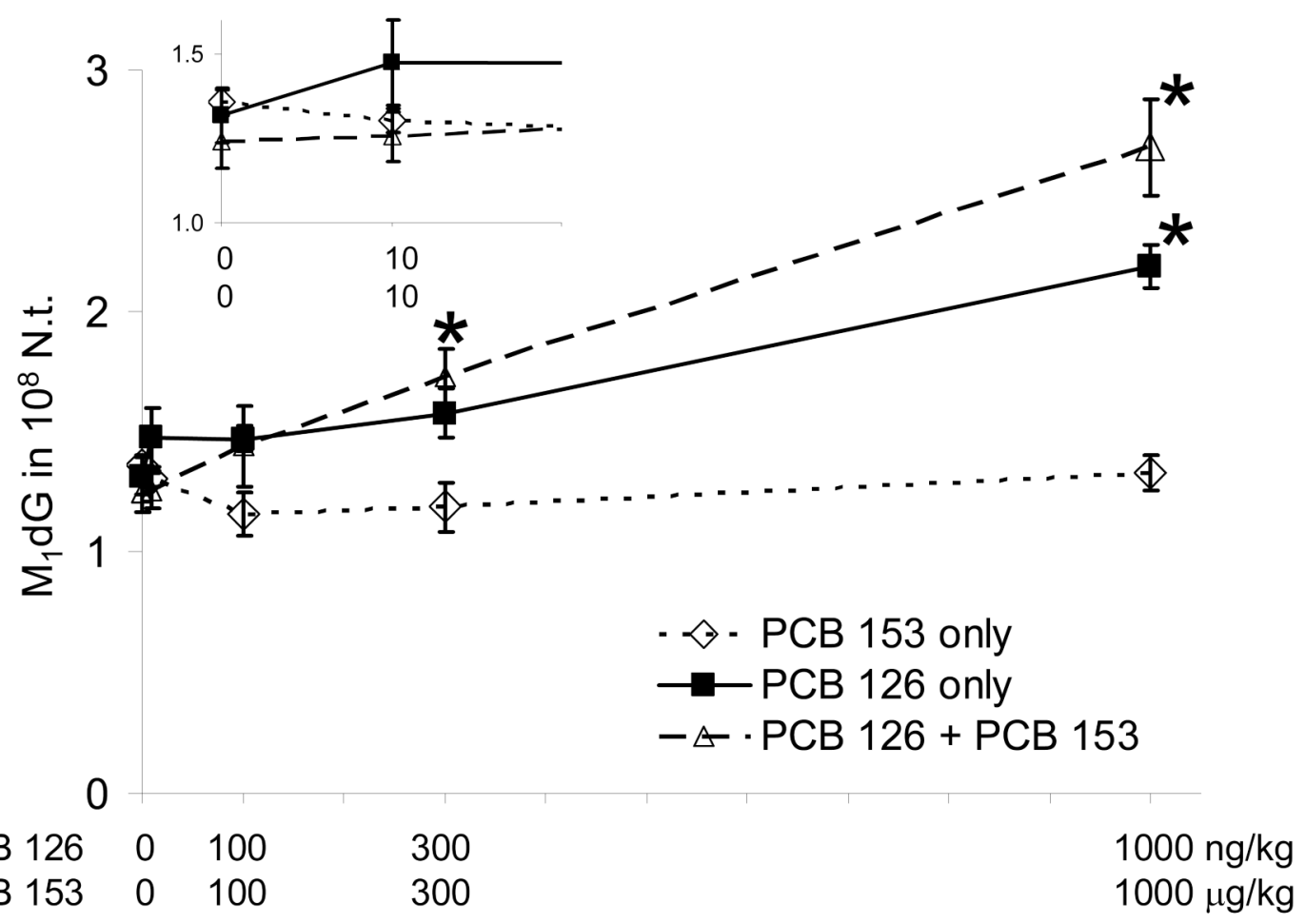

Fig. 4. Accumulation of $M_{1} d G$ DNA adducts in rat liver tissues after chronic exposure to PCBs Female Harlan Sprague-Dawley rats were treated with an aliquot of corn oil:acetone (99:1) containing PCB 153, PCB 126, or a mixture of PCB 126 and PCB 153 (1: 1000 mix, i.e., 100 $\mathrm{ng} / \mathrm{kg} / \mathrm{d}$ PCB $126+100 \mu \mathrm{g} / \mathrm{kg} / \mathrm{d}$ PCB 153) by gavage 5 days per week for 53 weeks. DNA was isolated from liver tissue and processed for $\mathrm{M}_{1} \mathrm{dG}$ analysis. $\mathrm{B}$ : The mixtures were prepared with a fixed amount of PCB $126(300 \mathrm{ng} / \mathrm{kg} / \mathrm{d})$ and with different amounts of PCB 153. Each point or bar represents the mean + S.E. from 7-8 samples for each group.

*: Statistical significance compared to corresponding control (Dunnett's test, $p<0.05$ ) 
A

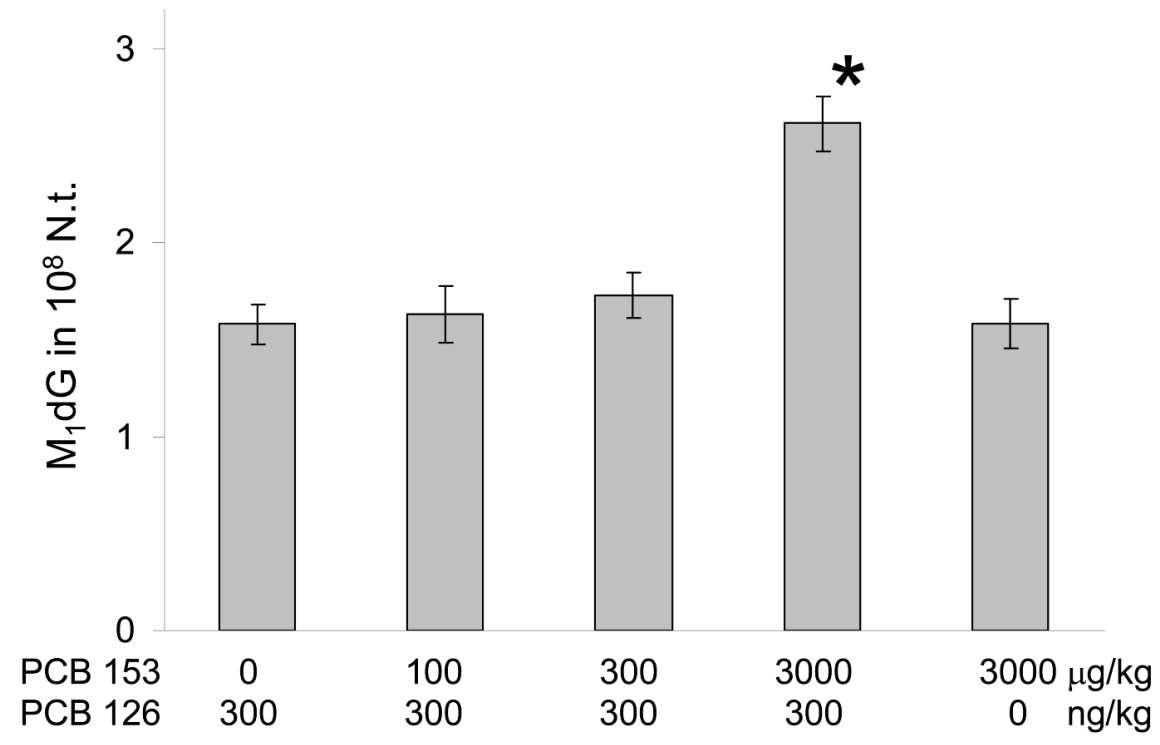

B

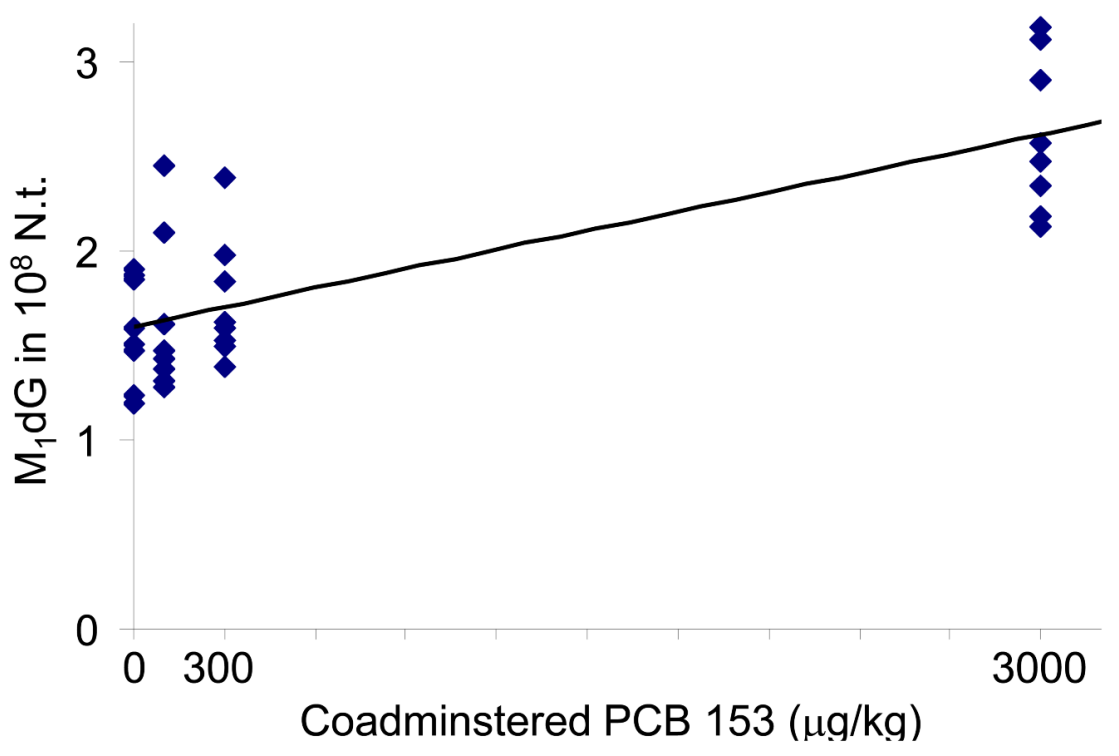

Fig. 5. Accumulation of $M_{1} d G$ DNA adducts in rat liver tissues after chronic exposure to mixtures of PCB 126 and PCB 153

Female Harlan Sprague-Dawley rats were treated with an aliquot of corn oil:acetone (99:1) containing either $3000 \mu \mathrm{g} / \mathrm{kg} / \mathrm{d}$ PCB 153 or a mixture consisting of fixed amounts of PCB 126 (300ng $/ \mathrm{kg} / \mathrm{d}$ ) and different amounts of PCB $153(0-3000 \mu \mathrm{g} / \mathrm{kg} / \mathrm{d}) . \mathrm{M}_{1} \mathrm{dG}$ adducts in liver DNA were analyzed with LC-MS/MS after selective labeling with tBHA (A). Each point or bar represents the mean + S.E. from 7-8 samples for each group. Correlation between the number of $\mathrm{M}_{1} \mathrm{dG}$ adducts and the amount of PCB 153 coadminstered with $300 \mathrm{ng} / \mathrm{kg} / \mathrm{d}$ PCB 126 was tested by linear regression (B). 
*: Statistical significance compared to $300 \mathrm{ng} / \mathrm{kg} / \mathrm{d}$ PCB 126 without PCB 153 (Dunnett's test, $p<0.05)$ 


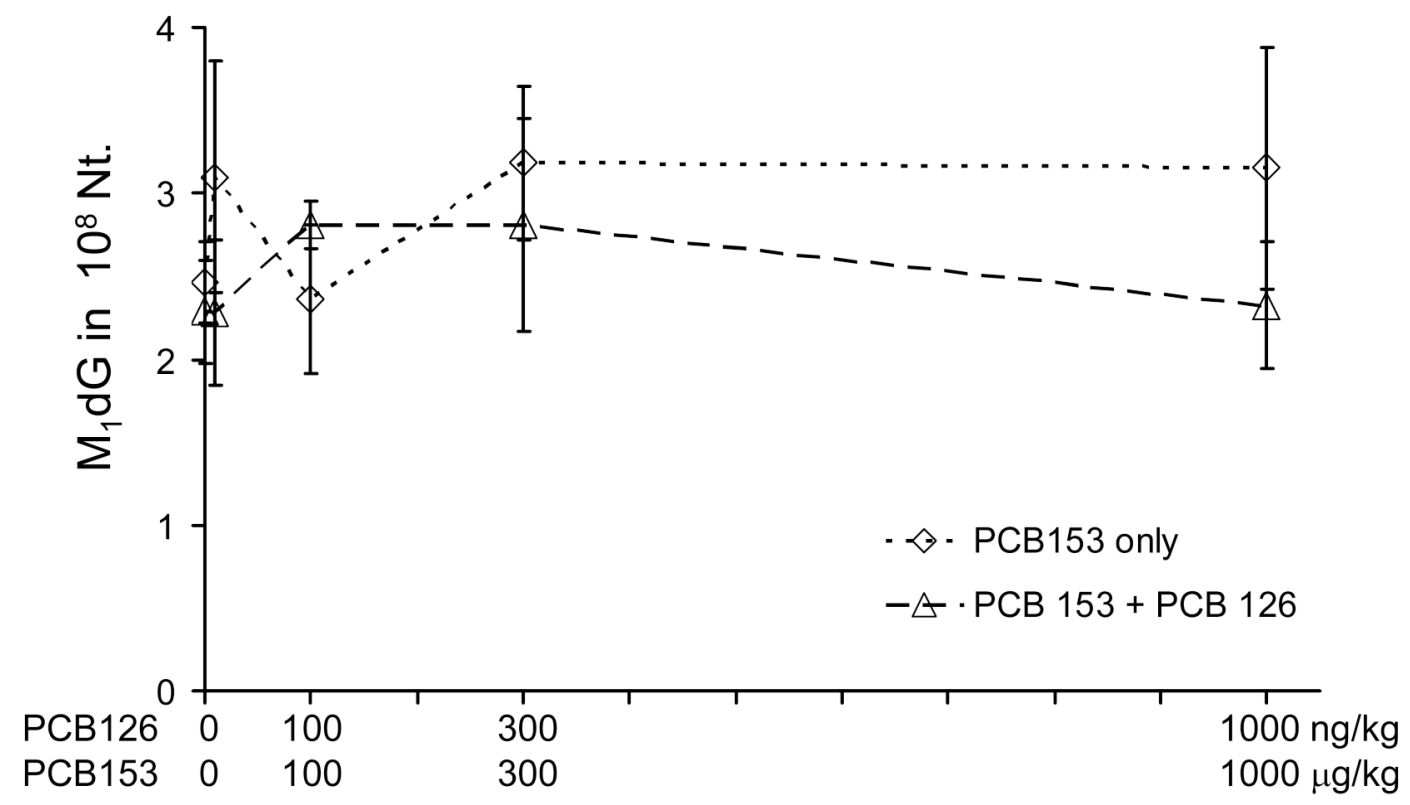

Fig. 6. Analyses of $M_{1} d G$ DNA adducts in brain tissues after chronic exposure to PCBs

Female Harlan Sprague-Dawley rats were dosed with an aliquot of corn oil:acetone (99:1) containing PCB 153 with or without PCB 126 by gavage 5 days per week for 53 weeks. DNA was isolated from brain tissue of the animals and processed for $\mathrm{M}_{1} \mathrm{dG}$ analysis. Each point represents the mean + S.E. from 4-5 samples for each group. 


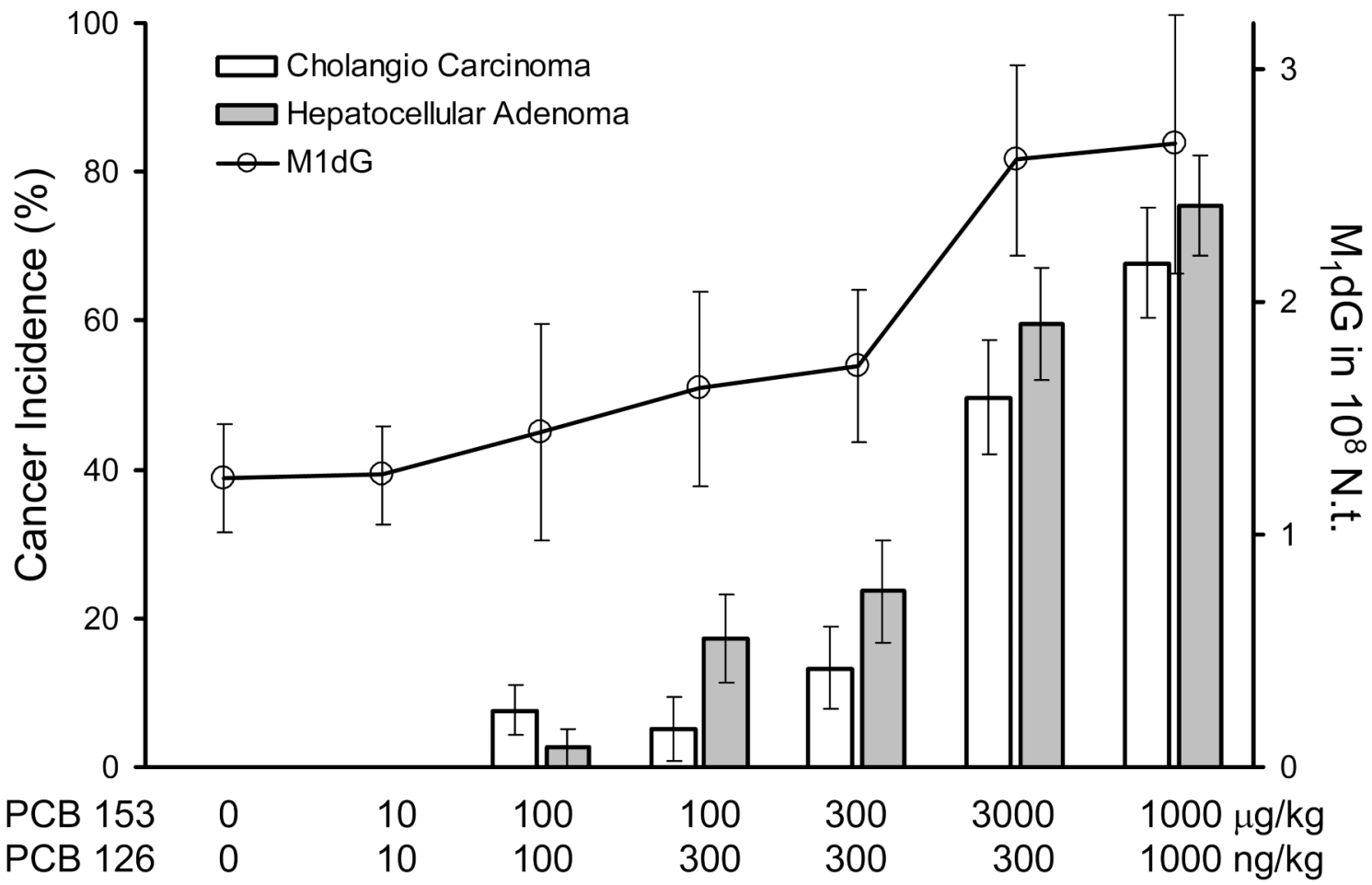

Fig. 7. Dose response for the formation of neoplastic lesions and for $M_{1} d G$ adduct accumulation in female rats treated with mixtures consisting of PCB 126 and PCB 153

The incidence of neoplastic lesions is Poly-3 estimated neoplasm incidence after adjustment for intercurrent mortality [30]. Each point represents the mean + S.E. 


\section{Composition of PHAH mixtures}

\section{Table 1}

\begin{tabular}{|c|c|c|c|}
\hline Mixture & РНАН & TEF & Mass Ratio \\
\hline \multirow{5}{*}{ Mix A } & TCDD & 1 & 1 \\
\hline & 1,2,3,7,8-pentachlorodibenzo-p-dioxin (PeCDD) & 1 & 1 \\
\hline & 2,3,4,7,8-Pentachlorodibenzofuran (4-PCDF) & 0.1 & 2 \\
\hline & $3,3^{\prime}, 4,4^{\prime}, 5^{\prime}$-pentachlorobiphenyl (PCB 126) & 0.1 & 45 \\
\hline & $2,3^{\prime}, 4,4^{\prime}, 5^{\prime}$-pentachlorobiphenyl (PCB 118 ) & 0.0001 & 10,000 \\
\hline \multirow{3}{*}{ Mix B } & $2,2^{\prime}, 3,4,4^{\prime}, 5^{\prime}$-hexachlorobiphenyl (PCB 138) & N/A & 20,000 \\
\hline & $2,2^{\prime}, 4,4^{\prime}, 5,5^{\prime}$-hexachlorobiphenyl (PCB 153) & N/A & 30,000 \\
\hline & $2,2^{\prime}, 3,4,4^{\prime}, 5,5^{\prime}$-hexachlorobiphenyl (PCB 180) & N/A & 20,000 \\
\hline Mix C & $\operatorname{Mix} A+\operatorname{Mix} B$ & & \\
\hline
\end{tabular}

Adapted from Burgin [28]. 